BIOKEMISTRI 17(1):39-43 (June 2005)

Available online at $h t t p: / / w w w . b i o l i n e . o r g . b r / b k$.

Abstracted online at www.ajol.info/journals/biokem

Printed in Nigeria
An international journal published by the<smiles>c1ccc(Sc2ccccn2)cc1</smiles>

OVigerian Society for Exxperimental ß̊iology

\title{
Pattern of serum total calcium, magnesium and zinc in human immunodeficiency virus disease/acquired immunodeficiency syndrome patients of Saki-West Local Government Area of Oyo state -Nigeria
}

\section{Mathew Folaranmi OLANIYAN}

\author{
Baptist Medical Centre, P.O.Box 43, Saki, Oyo State, Nigeria
}

Received 27 February 2004

MS/No BKM/2004/036, ( 2005 Nigerian Society for Experimental Biology. All rights reserved.

\begin{abstract}
Fifty HIV disease/AIDS seronegative subjects aged $23.6 \pm 16.5$ years (female=25: male $=25$ ) were recruited as normal control subjects. Thirty HIV disease/AIDS seropositive patients that presented with the symptoms of AIDS especially, aged 19.2 \pm 10.7years (female: 15 aged $22.0 \pm 12.1$ years: males $=15$ aged $20.6 \pm 11$.3years) were used as test subjects. Serum total calcium, magnesium and zinc were analysed using atomic absorption spectrophotometry and HIV tests were carried out on each of the subjects. There was no significant gender difference in the mean values of serum total calcium, magnessium and Zinc obtained from the HIV disease/AIDS seropositive females compared with those observed in their male counterparts $(\mathrm{p}>0.05)$. A lower significant mean value of serum total calcium, magnesium and Zinc was observed in the HIV disease/AIDS seropositive subjects compared to the mean values of the parameters observed in the normal control subjects $(\mathrm{p}<0.05)$. This work has therefore been used to study the pattern of serum total calcium, magnesium and Zinc in HIV/AIDS patients of Saki West local Government area through the analysis of the stated parameters. It has been found that the study of the parameters has further contributed to the understanding of the pathophysiology and the effect of the disease condition/syndrome on the mineral/nutritional status of HIVdisease/AIDS sropositive subjects.
\end{abstract}

Key words: HIV/AIDS, Pattern, Minerals, Serum

E-mail: olaniyanmat@yahoo.com 


\section{INTRODUCTION}

The Human Immunodeficiency Virus (HIV), a retrovirus identified in 1983 causes progressive impairment of the body's cellular immune system, leading to increased susceptibility to infections and tumours, and the fatal condition known as Acquired Immunodeficiency Syndrome [AIDS]. Human immunodeficiency virus has been described as the etiologic factor of acquired immunodeficiency syndrome [1].

Acquired immunodeficiency Syndrome represents one of the major public health problems of the $21^{\text {st }}$ century [1,2]. At the end of 1998, the joint United Nations Programme on HIV/AIDS (UNAIDS) estimated that globally there were 33.4 million people living with HIV/AIDS; more than $95 \%$ of those infected live in developing countries, about $70 \%$ in subSaharan Africa [1]. Anaemia (82\%), Leucocytosis (53\%), hypoalbuminaema (43\%), hyperglobulinaemia (88\%), elevated liver enzymes such as aspartate transaminase [AST],alanine transaminase [ALT] and hyponatreamia $(57 \%)$ were reported as the frequent laboratory findings in the study carried out earlier (3). The clinical manifestations of infections associated with AIDS tend to fall into well-recognized patterns of presentation, including pneumonia, dysphagia/odynophagia, diarrhoea, neurological symptoms like demmentia, fever, wasting, anaemia, and visual loss. Commonest pathogens when there is immunodepression especially due to HIV disease/AIDS infection include Candida albicans, Pneumocystis carinii, Mycobacterium tuberculosis Toxoplasma gondii, Cryptococcus neoformans, Mycobacterium avium intracellular and Cytomega lovirus [4]. The destruction of the immune system (and poor nutritional status due to malabsopion and anorexia) by the virus result in opportunistic infection, as well as an increased risk of auto immune disease and malignancy such as kaposis sarcoma and nonHodgkin's lymphoma [1, 4].

Deficiency of proteins, calories, fatty acids, Pyridoxine, folate, vitamins $\mathrm{A}, \mathrm{C}$ and $\mathrm{E}$ and Zinc affect the immune function [5]. Low serum calcium concentrations are found in gastrointestinal disease that interferes with the absorption of vitamin D and or calcium and in conditions of low serum protein [5-9].

Hypomagnesaemia is also frequently associated with gastrointestinal disorders such as malassorption, prolonged diarrhoea, bowel or kidney fistulas and acute pancreatitis found in HIV disease/AIDS patients. [6,8,10,11].

This work was designed to study the pattern of the serum levels of total calcium, magnesium and zinc in human immunodeficiency virus disease/Acquired immunodeficiency Syndrome patients.

\section{MATERIALS AND METHODS}

\section{Subjects/Study area}

(a) Thirty AIDS patients aged $20.6 \pm$ 11.3years (female $=15$ aged 19.2 \pm 10.7 years; male $=15$ aged $22.0 \pm 12.1$ years) living (for not less than ten years) in Saki-West Local Govrnment Area of Oyo State-Nigeria; that presented with the symptoms associated with AIDS especially;loss of weight; chronic diarrhoea, malabsorption, anorexia and pyrexia/fever were recruited into the study from the medical out patient Department of Baptist Medical Center, Saki-Oyo State-Nigeria as test subjects.

(b) Fifty HIV seronegative subjects aged $23.6 \pm$ 16.5years (female $=25$, male $=25$ ) were recruited as normal control subjects.

\section{Sample:}

Five milliliters of venous blood was collected from each of the subjects in the two subject groups into specimen bottles without anticoagulant. The serum was extracted for the analysis of serum total calcium magnesium and zinc, and HIV tests by spinning the clotted blood using bench centrifuge at $1000 \mathrm{rpm}$ for $10 \mathrm{mins}$ $[1,12,13]$. Each of the subjects was tested for HIV/AIDS.

\section{Methods:}

HIV/AIDS tests were carried out on each of the subjects using HIV screening by the Genie IIHIV 1/2-9 a dual recognition Enzyme 
immunoassay (EIA): a kit of bioRad, 3-boulvard Raymond Poincare 92430 Marnesla CoquetteFrance and western blot assay was used for confirmation. All subjects were pre and post-test counseled. Serum total calcium, magnesium and zinc were analysed by Atomic Absorption spectrophotometry (Perkin-Elmer Corporation, Norwalk CTO 6856).The parameters were analysed by deprotinizing the serum,followed by the dilution of the deprotinised serum[ for zinc serum was diluted five fold with deionized water;for calcium serum was diluted fifty fold in $0.1 \%$ Lanthanium Chloride; and for magnesium 1:50 with deionized water] and aspirated into the spectrophotometer following the procedure of Perkin Elmer spectrophotometer $[6 ; 12 ; 13]$.

\section{Principle:}

Monochromatic light for a particular element is produced by means of a hollow cathode lamp using that element as the cathode. The monochromatic light is beamed through a long flame into which is aspirated the solution to be analysed . The heat energy dissociate's the molecules and convert the components to atoms; although some atoms are activated, most atom remain in the ground state at the temperatures commonly used. The ground state atoms of the same elements as in hollow cathode cup absorb their own resonance lines; the amount of light absorbed varies directly with their concentration in the flame. The transmitted light that is not absorbed reach the monochromator which passes only the wavelength close to the selected resonance lines of the particular element to be assayed. The transmitted light strikes a detector, and the decrease in transmitted light is measured [6].

\section{Statistical analysis:}

This was carried out using Student ' $t$ ' test described by Norman, 1994 [14]

\section{RESULT}

The results of this study are as shown in tables 1 and 2 below. There was no significant difference in the mean values of serum total calcium, magnesium and zinc in the results obtained from the HIV/AIDS seropositive female subjects aged compared to the mean values of these parameters observed in the HIV/AIDS seropositive male subjects. Higher significant mean values of calcium, magnesium and zinc were observed in the HIV/AIDS seronegative control subjects than mean values of serum total calcium, magnesium and zinc observed in the HIV/AIDS seropositive subjects.

TABLE 1: The mean and standard deviation ( $x \pm$ S.D) of the serum level of Calcium, Magnesium and Zinc of the test and the control subjects

\begin{tabular}{|l|l|l|l|l|l|}
\hline & $\mathrm{N}$ & $\begin{array}{l}\mathrm{Ca} \\
(\mathrm{mmol} / \mathrm{L})\end{array}$ & $\mathrm{Mg}(\mathrm{mmlo} / \mathrm{L})$ & $\begin{array}{l}\mathrm{Zn} \\
(\mu \mathrm{mol} / \mathrm{L})\end{array}$ & Age (years) \\
\hline $\begin{array}{l}\text { HIV/AIDS } \\
\text { Seropositive } \\
\text { females }\end{array}$ & 15 & $1.75 \pm 0.2$ & $0.58 \pm 0.15$ & $10.2 \pm 1.2$ & $19.2 \pm 10.7$ \\
\hline $\begin{array}{l}\text { HIV/AIDS } \\
\text { Seropositive } \\
\text { males }\end{array}$ & 15 & $1.73 \pm 0.2$ & $0.58 \pm 0.14$ & $10.1 \pm 1.1$ & $22.0 \pm 12.1$ \\
\hline $\begin{array}{l}\text { HIV/AIDS } \\
\text { Seropositive Test } \\
\text { subjects } \\
{\left[\begin{array}{l}\text { Females and } \\
\text { males }]\end{array}\right.}\end{array}$ & 30 & $1.74 \pm 0.19$ & $0.58 \pm 0.14$ & $10.2 \pm 1.1$ & $20.6 \pm 11.3$ \\
\hline $\begin{array}{l}\text { HIV/AIDS } \\
\text { Seronegative } \\
\text { control subjects }\end{array}$ & 50 & $2.1 \pm 0.13$ & $0.71 \pm 0.16$ & $14.6 \mathrm{v} 3.0$ & $23.6 \pm 16.5$ \\
\hline
\end{tabular}


TABLE 2: ' $t$ ' test and 'probability (p) values of the subject groups.

\begin{tabular}{|l|l|l|l|l|l|}
\hline $\begin{array}{l}\text { HIV/AIDS seropositive } \\
\text { subjects }\end{array}$ & 't' & 9.0 & 3.3 & 9.4 & 0.96 \\
$\begin{array}{l}\text { Vs } \\
\text { HIV/AIDS seronegative } \\
\text { control subjects }\end{array}$ & 'p' & $\begin{array}{l}\mathrm{P}<0.05 \\
\text { significant }\end{array}$ & $\begin{array}{l}\mathrm{P}<0.05 \\
\text { significant }\end{array}$ & $\begin{array}{l}\mathrm{P}<0.05 \\
\text { significant }\end{array}$ & $\begin{array}{l}\text { P>0.05 Not } \\
\text { significant }\end{array}$ \\
\hline $\begin{array}{l}\text { HIV/AIDS seropositive } \\
\text { females } \\
\text { Vs }\end{array}$ & 't' & 0.27 & 0 & 0.23 & 0.7 \\
HIV/AIDS Seropositive males & 'p' & $\begin{array}{l}\text { P }>0.05 \\
\text { Not } \\
\text { significant }\end{array}$ & $\begin{array}{l}\text { P>0.05 Not } \\
\text { significant }\end{array}$ & $\begin{array}{l}\text { P>0.05 Not } \\
\text { significant }\end{array}$ & $\begin{array}{l}\text { P>0.05 Not } \\
\text { significant }\end{array}$ \\
\hline
\end{tabular}

\section{DISCUSSION}

The significantly reduced serum levels of calcium, magnesium and Zinc found in HIV disease/AIDS seropositive subjects compared with the control can be attributed to the frequent chronic diarrhoea, anorexiaand probably malabsorption of food substances associated with HIV disease/AIDS infection [5,6,7,9].

The reduced serum levels of magnesium and calcium in the test subject compared with the control is also consistent with the report of [6] that hypomagnesaemia and low total calcium level in the serum can be associated with gastrointestinal disease such as malabsorption and diarrhoea common in HIV disease/AIDS patients.

Low calcium, magnesium and zinc serum levels in the HIV/AIDS seropositive subjects is also attributable to the low level of the binding protein (hypoalbuminaemia) found in HIV/AIDS seropositive subjects [3,6,9] .Decreased concentration of the serum level of zinc in the test subjects compared with the HIV/AIDS seronegative subjects is consistent with the findings of $[3,9]$ that reported deficiency of zinc in HIV/AIDS patients.

The result of this study is also consistent with the fact that poor nutritional status which may result from malabsorption,loss of apetitte, diarrhoea and vomiting common in HIV disease/AIDS patients, is one of the major contributing factors for patients to be immunodeficient $[1,5,9]$.
The present work has therefore been used to study the pattern of serum levels of calcium, magnesium and zinc in HIV disease/AIDS. The study is therefore useful in the understanding of the pathophysiology of Acquired Immunodeficiency Syndrome and the effect of the syndrome on the parameters studied.

\section{REFERENCES}

1. Cheesbrough M. (2002) District Laboratory practice in Tropical countries part 2 Cambridge University Press U.K. Cambridge low price reprinted edition: pp 252-264.

2. Gray R, Brewin E, Noak J, WekeJoseph Jand Sonik B. (2002) A review of the literature on HIV infection and schizophrenia: Implications for research policy and clinical practice. Health services Research Department, institute of psychiatry, London, UK.R. $J$. Psychiatr Ment Nurs. 9:4

3. Yoong KY. and Cheong I. (1997) A study of Malaysia drug addicts with human immunodeficiency virus infection. International Journal of STD and AIDS 8: 118-23.

4. Loyd A. (1996) HIV infection and AIDS (Review) Papua New Guinea Medical Journal 39:174-80.

5. Swati-Sherlekar SA (2002) Role of Nutrition in the management of HIV infection /AIDS JIMA 100: 1-6 
6. Kaplan A, Szabo L. L. and Ophein K. E. (1998) Clinical chemistry: Interpretation and Techniques. Lea \& Febiger 600 Washinton square Philadelphia, USA. Third edition: Pps 145-165 and 319-335.

7. Ehrenpreis ED, Carlson SJ., Boorstein HL and Craig RM (1994) Malabsorption and deficiency of vitamin $\mathrm{B}_{12}$ in HIV infected patients with chronic diarrhea. Dig Dis Sci 39: 21592162.

8. Gillin JS, Shike M, Alcock N, Urmacher C, Krown S, Kuitz RC, Lightdale CJ and Winawer SJ. (1985) Malabsorption and mucosal abnormalities of the small intestine in the acquired immunodeficiency syndrome. Ann intern Med. 102: 619622.

9. Huang CM, Ruddel M and Elim RJ. (1988) Nutritional status of patients with acquired immunodeficiency syndrome. Clin Chem. 34: 1957-1959.

10. Carlson S, Yokoo $\mathbf{H}$ and Craig RM. (1994) Small intestinal HIV-associated enteropathy: evidence for panintestinal enterocyte dysfunction. $J$ Lab. Clin. Med. 124: 652-659.

11. Ehrenpreis ED, Ganger Dr, Kochvar GT, Patterson BK and Craig RM (1992) D-xylose malabsorption: characteristics finding in patients with the AIDS wasting syndrome and chronic diarrhea. J. Acquire immune Deficiency syndr. 5: 1047-1050.

12. Sprague, S. and Slavin, W (1965) Analysis of serum Determination of Zinc. Atomic. Absorp. Newsletter 4:28.

13. Fernadez, F. J. (1966) Analysis of serum determination of calcium. Atomic Absorp. Newsl. 5: 256.

14. Norman J. J. (1994) Bailey Statistical methods in biology. Cambridge University Press. Cambridge Low price third edition. pps1-38

15. Kotler DP, Gaetz HP, Lange M, Klain EB and Hoit PR. (1984) Enteropathy associated with the acquired immunodeficiency syndrome. Ann. Intern. Med. 101: 421-428. 